\title{
11. Traditional and 'modern' trepang fisheries on the border of the Indonesian and Australian fishing zones ${ }^{1}$
}

\author{
Dedi Supriadi Adhuri
}

\section{Introduction: A history of trepang fisheries}

Fishing for trepang is one of the oldest practices of maritime resource exploitation. Its story started in China, the country where trepang consumption was and still is common. In China, trepang is called hai-sen or sea ginseng. The first reference to hai-sen was found in a sixteenth-century work, the Shih-wu pet-ts ao, which outlined the use of trepang in relation to various substances of medical use (Macknight 1976, p. 7). Another book, the Miscellanies of Five Items, which was published in 1602, describes trepang as an aphrodisiac (Schwerdtner Máñez and Ferse 2010). Later in the same century, trepang is mentioned more frequently in Chinese literature. One could suggest that with this increase in familiarity the habit of using trepang has been progressively gaining popularity in China.

In terms of an explanation for the Chinese demand for trepang, it seems that the coastal waters of China did not have much trepang, and what was there was not of high quality (Macknight 1976, p. 8). At the same time, demand was increasing, and in the same century it outstripped domestic supply. Once it was clear that supply from China's mainland coastal waters could not meet the demand for trepang, expansion into external markets started in earnest. The expansion led to the exploitation of Southeast Asian waters and eventually to the coastlines of Australia and the Pacific Islands.

The development of trepang exploitation in Indonesia started not long after, thus by the 1720s trepang fisheries were relatively well established. This is shown both by the quantities of trepang being exported from Makassar, the

\footnotetext{
1 I thank The Australian National University's College of Arts and Social Sciences for sponsoring my six week visit to Canberra, where I was able to write the body of this chapter. I would like to express my thanks and appreciation to Dr Marshall Clark, who acted as my personal host and provided comments and corrections on several earlier versions of this chapter. Dr Jim Prescott has provided me with key information on the English and Latin names of the trepang discussed in this chapter. He also kindly shared important information on the Oelaba fishers. Dr Michelle Carnegie has helpfully commented on an earlier version of this chapter. $\mathrm{Mr}$ James Riwu accompanied me on my visit to Oelaba village in 2011 and I express my gratitude to him.
} 
centre of the trepang trade in Indonesia (see Table 11.1), and by the broad level of trepang exploitation. Historical reports describe trepang fishing being carried out all over eastern Indonesia. Maluku (including Kei and Aru), South Sulawesi, Buton, Selayar, Spermonde Islands, Sumbawa, West Papua and Timor are noted by the Dutch and others for the presence of trepang fishing (Schwerdtner Máñez and Ferse 2010; Sutherland 2000).

Indonesian fishers also have a history of using what can be termed as Australian waters. These include those around Ashmore Reef, Scott Reef, Seringapatam Reef, Cartier Island and even further south to Marege' (Arnhem Land) and Kayu Jawa (the Kimberley), since at least the 1750s (Macknight 1976). The Indonesian fishers involved in trepang fishing in these areas were identified as Makassarese, Butonese, Bugis, Bajau and Madurese (Fox and Sen 2002). In the literature they are commonly labelled with the generic term 'Macassans'; but, in light of his reading of the official reports of the Vereenigde Oostindische Compagnie (VOC), or Dutch East India Company, Fox (1977) argues that it was not the Makassarese who first fished in Australian waters but rather the Bajau people, who reached Kupang on Timor Island in the 1720s. He notes that one of the reasons for the Bajau voyaging to Timor is to collect trepang. In fishing for the trepang, the Bajau did not stop at Timor but sailed south, where they 'accidentally' found Ashmore Reef. It was only in the 1750s that the Makassarese vessels were reported to have begun arriving en masse in the Timor Sea, sailing south-southeast from Makassar to collect trepang in the vicinity of Ashmore Reef. Also by accident, according to Flinders, they found trepang to be more abundant along the New Holland (mainland Australian) coast in the second half of the eighteenth century (Macknight 1976, p. 93). This was the beginning of the establishment of the Macassan trepang industry in Marege' and Kayu Jawa, an industry that lasted until the early twentieth century.

Table 11.1 Trepang exports from Makassar, 1717-1917

\begin{tabular}{|r|r|}
\multicolumn{1}{|c|}{ Years } & Amount in tons \\
\hline $1717-26$ & 157 \\
\hline $1733-34$ & 71 \\
\hline $1766-69$ & 640 \\
\hline $1774-77$ & 844 \\
\hline $1786-89$ & 1304 \\
\hline $1796-97$ & 154 \\
\hline $1820 s$ & $\sim 430$ \\
\hline $1832-34$ & $<568$ \\
\hline $1868-70$ & 1504 \\
\hline $1871-78$ & 3478 \\
\hline $1915-17$ & 1637 \\
\hline
\end{tabular}


Political and economic development in Australia and the expansion of its marine territory drove the Macassans from the Australian coastal territories. For Ashmore Reef and its surrounding islands, the process of exclusion started with American whalers' discovery of large deposits of guano on islands in the northwest Kimberley region in the 1840s (Stacey 2007, p. 83). This discovery instigated competition between the Americans and the British, who had an interest in the guano business. In turn, this competition led to the annexation of Ashmore Reef and Cartier Island by the British in 1878 and 1909 respectively. Fisheries, especially trepang, became a contested resource. In 1909, for example, an Australian trepang businessman complained to the Secretary of State for the Colonies in London about fishers from the Dutch East Indies who were interfering with his trepang fishing operation (Bach 1955, p. 208).

The Macassan trepang industry in Arnhem Land and the Kimberley coast faced similar concerns. The emergence of an Australian-based trepang industry in the 1870s (Macknight 1976, pp. 101-3) made the presence of the Macassans in the territory awkward. Subsequently, the Australian Federal and local governments created several new regulations, eventually leading to the termination of the Macassan trepang industry in 1907 (Macknight 1976; Stacey 2007).

The expansion of Australian waters to 200 nautical miles from the coastline, declared in 1979, pushed Indonesian fishers further to the north. Subsequent agreements between the Indonesian and Australian governments concerning marine boundaries between the two countries, which were finalised in 1997, reaffirm the exclusion of Indonesian fishers from Australian waters. An exception to this is an area popularly called the MoU Box: the waters surrounding Ashmore Reef, Scott Reef, Seringapatam Reef and Cartier Island. In this area, Indonesian traditional fishers are allowed to conduct some fishing activities (see the next section for more detail).

Interestingly, however, in spite of these formal government agreements, trepang collecting in the border areas, legal and illegal (Fox 2009), has never completely ceased. For example, Figure 11.1, which shows the apprehension of Indonesian fishers fishing in Australian waters between 1997 and 2009, demonstrates that fishing activities in the border zone of the two countries continue until the present day. Of course, we also note that since 2006 the number of apprehensions has decreased significantly; but, we should note that this has taken place after the Australian Government, under the prime ministership of John Howard in particular, spent many additional millions of dollars to increase border operations. Additionally, in my visit to the two localities, which will be discussed shortly, I found that fishing activities were still taking place, at least until the end of 2010 . 
FFV Apprehensions \& Legislative Forfeitures

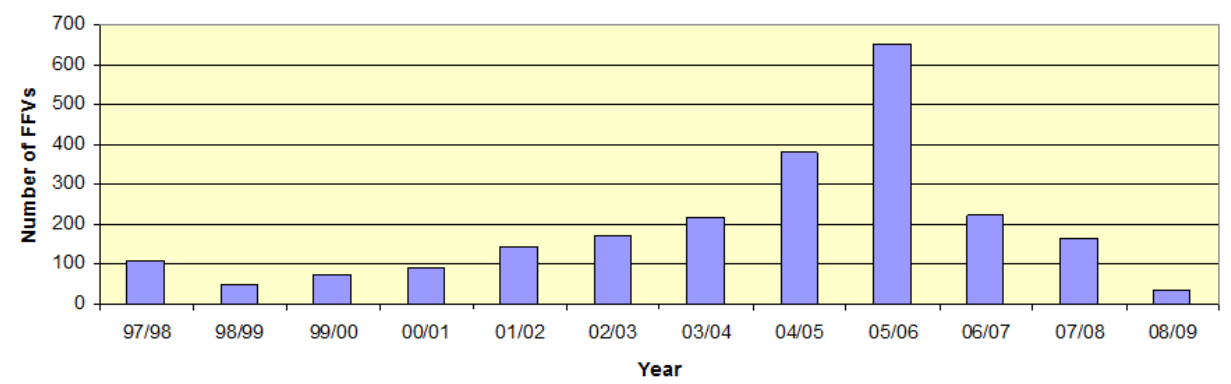

Figure 11.1 Apprehension of Indonesian Fishers in the Australian Fishing Zone (AFZ), 1997-2009

Source: Wilson (2009)

Who are these fishers? What are the characteristics of their fishing activities? What is their relation to the traditional voyages to Australian waters? These are important questions. Using the two fishing communities Oelaba on Rote and Oesapa in Kupang as examples, this chapter will discuss the characteristics of trepang fisheries that are currently operating along the border zone of Indonesia and Australia. These two communities embody a contrast between, on the one hand, 'traditional' trepang fishery practices and, on the other hand, 'modern' practices of trepang fishing. I will compare the socioeconomic characteristics of both communities, framed by the underlying technological differences between the two, as well as the management consequences.

\section{Setting the stage: Defining 'traditional' and 'modern' fisheries}

In 1974, the Indonesian and Australian governments signed an agreement concerning Indonesian fishers fishing in Australian waters. This memorandum of understanding (MoU), which is popularly known as 'the $1974 \mathrm{MoU}^{\prime}$, is an acknowledgment of the historical role of traditional fishing in Australian waters. The MoU states that the traditional fishers of Indonesia are allowed to fish within $12 \mathrm{~nm}$ of five small islands in the waters of northern Australia. This includes the waters around Ashmore Reef, Cartier Island, Scott Reef, Seringapatam Reef and Browse Island (see Figure 11.2). The MoU also notes that 'Indonesian fishermen will not be permitted to take turtles in Australian waters', but they are permitted to take 'trochus, bêche-de-mer [trepang], abalone, green snail, sponges and all molluscs' from the seabed adjacent to the five reefs and islets specified in the agreement. 


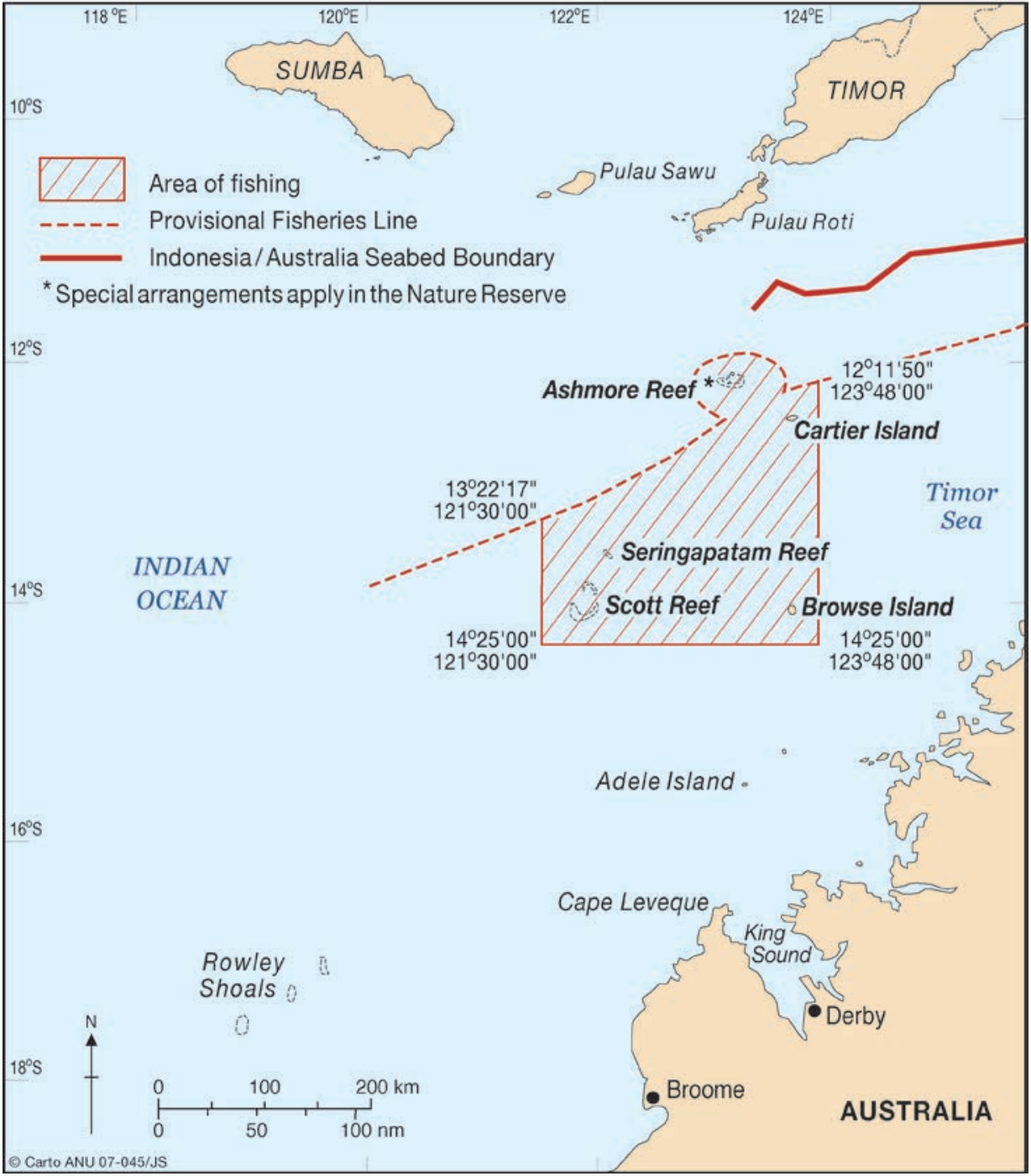

\section{Figure 11.2 The MoU Box}

Source: Stacey (2007, p. 202)

This agreement explicitly uses the term 'traditional fishermen' and provides its definition as follows: "By "traditional fishermen" is meant the fishermen who have traditionally taken fish and sedentary organisms in Australian waters by methods which have been the tradition over decades of time.'2

2 This is the second attempt of the Australian Government to directly address Indonesian fishing in Australian waters. The first was in 1968, when a decision was made to permit traditional Indonesian fishing 
In 1989, the definition of 'traditional fishermen' was clarified with some clauses of explanation. For instance: Access to the MOU area would continue to be limited to Indonesian traditional fishermen using traditional methods and traditional vessels consistent with the tradition over decades of time, which does not include fishing methods or vessels using motors or engines' (my emphasis).

This clarification means that the defining characters of tradition are: 1) the fishing methods, and 2) the fishing vessels. Both gear and vessels that are considered traditional are those that have been used over decades and are nonmotorised. Interestingly, this agreement does not define who 'traditional' fishers are. So, it does not problematise whether they are those who used to work the Australian waters in the past, their descendants or just any Indonesian citizen. This means that the MoU Box has become an open-access area for thousands of Indonesian fishers who do not use motorised vessels and gear.

Both governments have revisited the $1974 \mathrm{MoU}$ in light of how it has been utilised. In 1989, the two governments revised the agreement. The 1989 revision accommodates the fact that Ashmore Reef has been declared a National Nature Reserve since 1983. Subsequently, this area has been closed to any fishing activities. The revision also notes that Indonesian traditional fishers are allowed to fish in an area wider than the $12 \mathrm{~nm}$ mentioned in the $1974 \mathrm{MoU}$. A map showing the new spatial MoU Box was attached to the agreement.

Another area of concern is that 1974 MoU's definition of traditional fishers implies that fishers who do not possess the characteristics outlined above automatically fall into the categories of 'non-traditional' or 'modern' fishers. This means that fishers of this type are not allowed to access or exploit the MoU Box area or any other part of Australian waters, for that matter.

Outside the MoU Box area, the Indonesian and Australian governments have established a number of agreements that have led to fishing activities in the border area becoming quite complicated affairs. These agreements include regulations on the continental shelf and the Economic Exclusive Zones. The most recent agreement between the two countries, signed in 1997, states that both countries consent to the presence of an overlapping claim of the maritime border (Commonwealth of Australia 1997). It is agreed that in this area Indonesia has rights over the water column while Australia has rights over the seabed. Consequently, Indonesia has the right to manage the fisheries resources on the water column, but has no right to manage anything on the seabed. This includes sedentary resources that inhabit the seafloor such as trepang and trochus. These resources are under the management of Australian authorities.

to continue within the $12 \mathrm{~nm}$ territorial sea zone adjacent to Ashmore and Cartier islands, Seringapatam Reef, Scott Reef, Browse Island and Adele Island, providing operations were confined to a subsistence level (Stacey 2001). The first attempt, however, did not mention the terms 'tradition' or 'traditional' as in the MoU of 1974. 
The remainder of this chapter will adopt the above definitions for its discussion of the two fisheries of Oelaba and Oesapa. Based on these definitions, the two fisheries can be categorised as two different forms of fishing practice. These definitions, by the way, continue to be used by the Australian authorities in protecting their marine territories.

\section{The Oelaba-based trepang fishery}

Oelaba is a sub-village of Oelua village situated on the north coast of western Rote (see Figure 11.3). By 1997 it was home to 685 people living in 143 households (Fox and Sen 2002). Carnegie (2008) notes that by 2004 the number of households had increased to 178; Carnegie also found that almost one-third (27 per cent) of Oelaba people were Rotinese Muslim households of mixed ethnic heritage. Considering the key themes of this book, it is important to note that the migratory ancestors of the Rotinese Muslims in Oelaba sub-village are from the three most prominent maritime trading groups in eastern Indonesianamely, the Bugis, Butonese and Makassarese. Like the Macassans of centuries past, they are all originally from the island of Sulawesi (South and southeast Sulawesi to be precise). Together with the Bajau, these ethnic groups were those who established the trepang fisheries tradition.

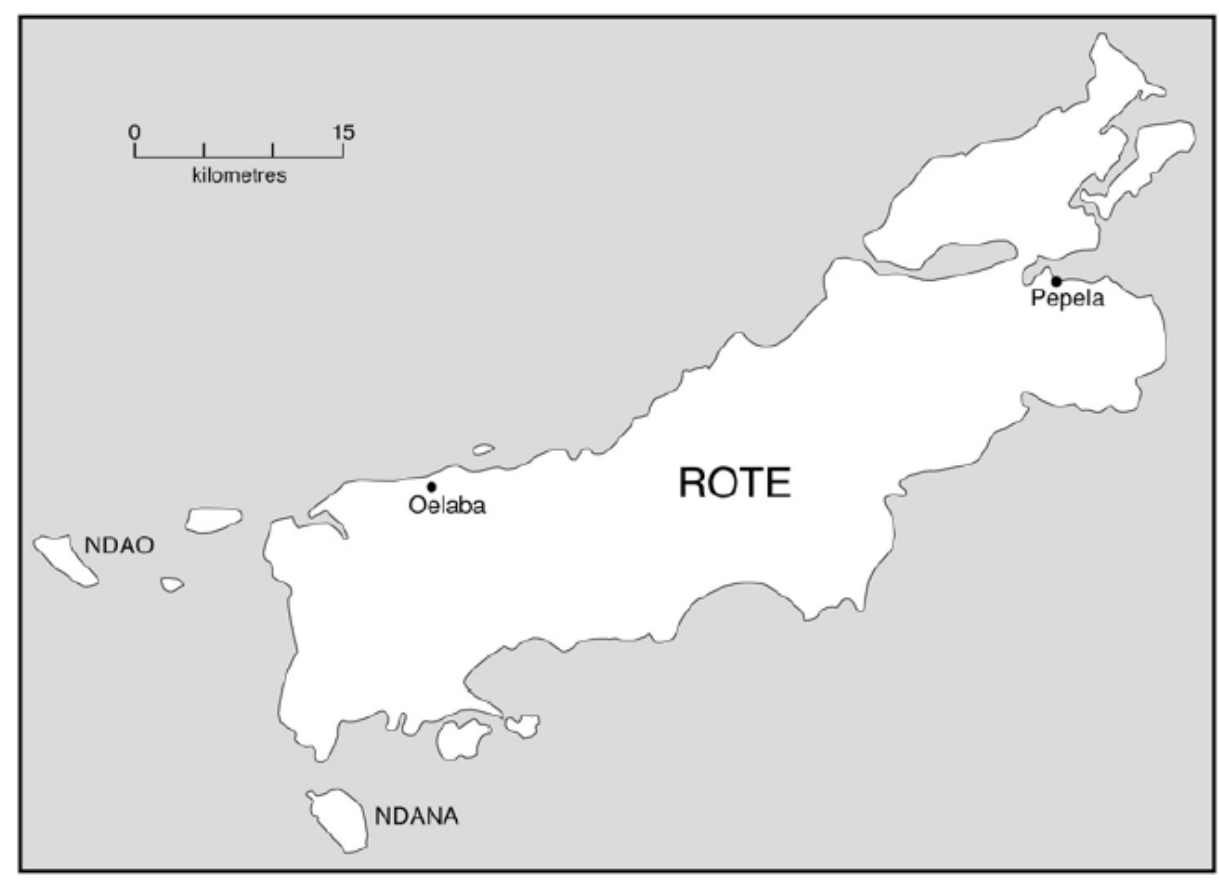

Figure 11.3 Rote Island 
The primary livelihood of the Oelaba inhabitants was originally inter-island trade and sailing. In the 1980s the Oelaba people started to get involved in trepang fishing in the MoU Box. In this regard, Carnegie (2008, p. 212) notes:

In response to this declaration of a special area set aside for any Indonesian in a non-motorised sailing boat to legally enter and extract valuable marine resources, such as trepang and trochus, in the 1980s a few Oelaba sailor-traders removed their boat motors and began sailing to the AFZ [Australian Fishing Zone].

The interest of Oelaba sailor-traders in becoming trepang fishers is also partly because the older players of the trepang fishery in the MoU Box region, such as the Macassan mixed-ethnics and the Bajau from Pepela (another village on Rote, see Figure 11.3), shifted their target species to shark fin, due to a rapid increase in the price of shark fin in the 1980s. A by-product of this shift is that it opened up a new opportunity for the Oelaba sailor-traders to fill a niche that became available when the Pepela fishers moved out of trepang gathering and into shark fishing. Subsequently, the number of boats from Oelaba journeying to the MoU Box has gradually increased over the years. In 2004, 39 sailing boats from a total of 42 in Oelaba sailed to the Australian waters (Carnegie 2008, p. 213).

The fishing practices of the Oelaba fishers can be regarded as 'traditional' insofar as the chosen fishing methods and vessel type align with the stated definition of a 'traditional' fishery, as outlined in the MoU Box agreement. Some of the vessels, known as lambo, used to have engines installed, but for the purpose of fishing in the MoU Box area the engines are systematically removed. Thus, the vessels that are between 10 and 20 gross tonnes have become what could be classed as 'sail-powered' boats. The fishing techniques and equipment used for trepang collection are also 'traditional' and in this sense quite simple. These include wading in shallow water collecting trepang barehanded, using ladong (a spear for catching trepang), or free diving. The last is mostly conducted by 'visiting' or 'invited' fishers from Alor, who are considered much better divers. ${ }^{3}$ Additional equipment used includes torches, canoes and firewood for cooking and post-harvest processing (Figure 11.4). For the last process in particular, the fishers boil the trepang catch before drying it in the sun. All post-harvest processes are carried out on the boat.

3 As noted earlier, the Oelaba trepang fishers are not traditional free divers, rather they are traders and sailors. Even those who fish in the inshore waters conduct fishing from their canoes. Diving is not part of this fishing practice. 
11. Traditional and 'modern' trepang fisheries on the border of the Indonesian and Australian fishing zones

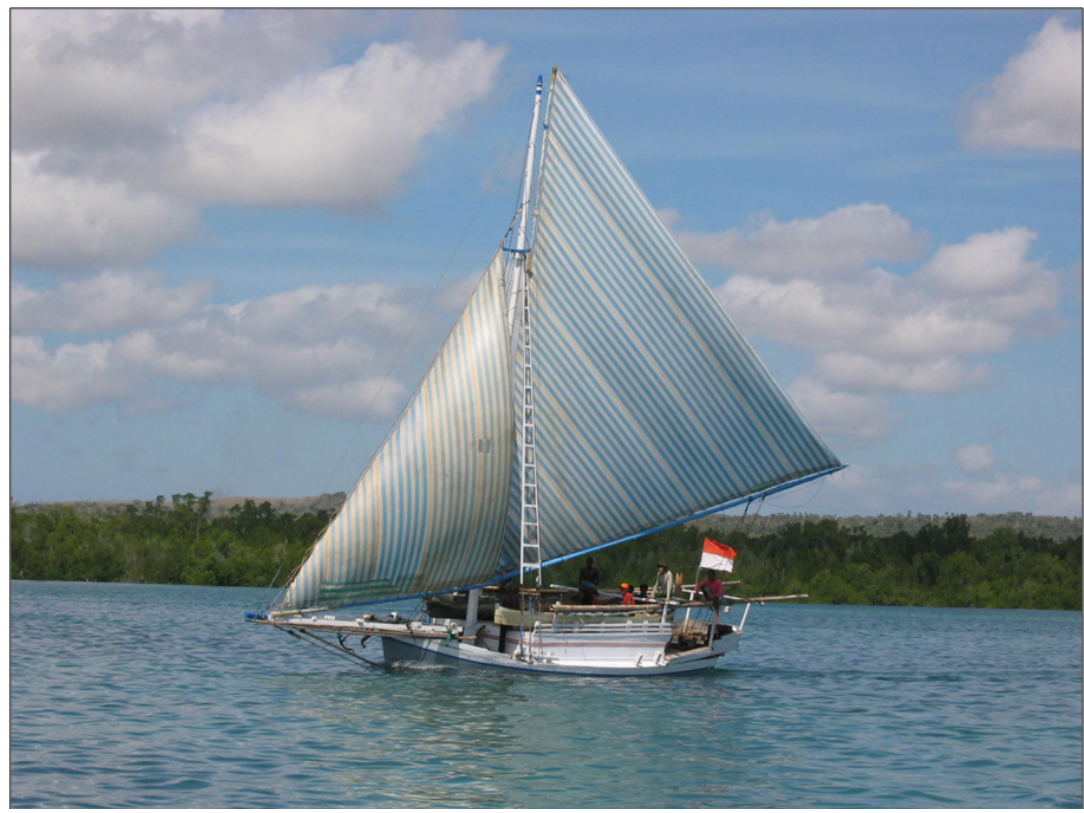

Figure 11.4a Sailing lambo

Source: Michelle Carnegie

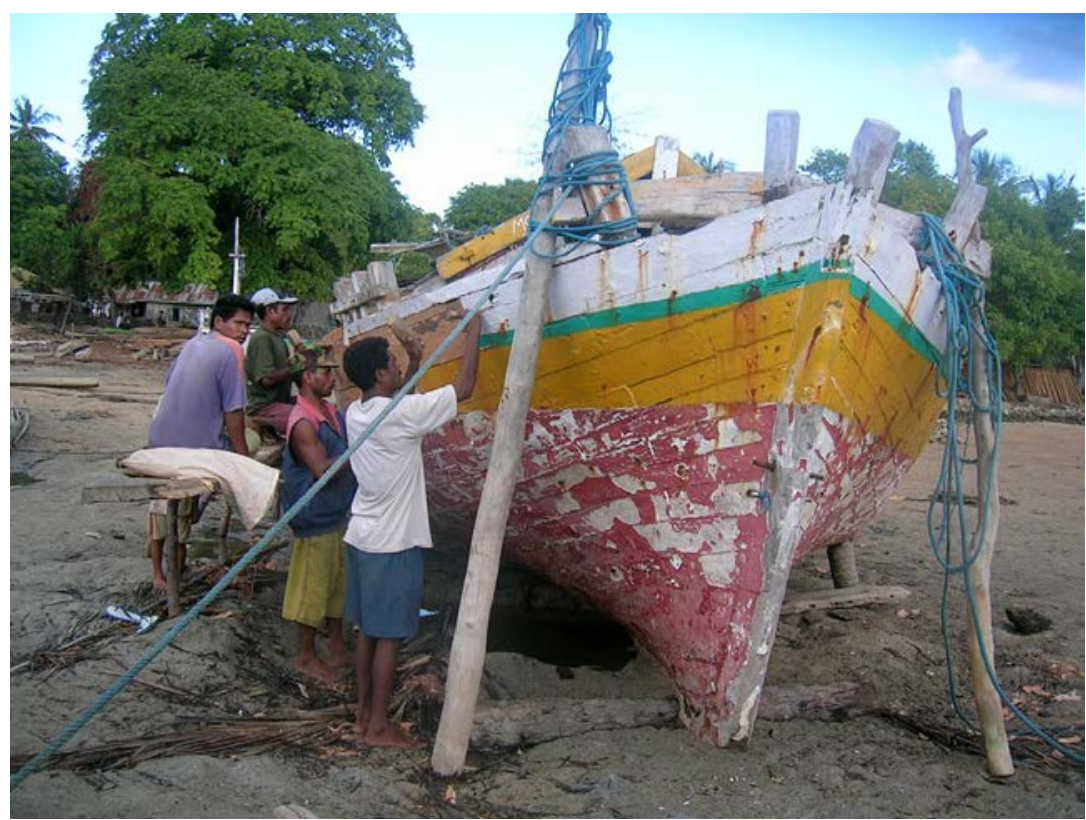

Figure 11.4b Some fishers are preparing their lambo

Source: Dedi Supriadi Adhuri 


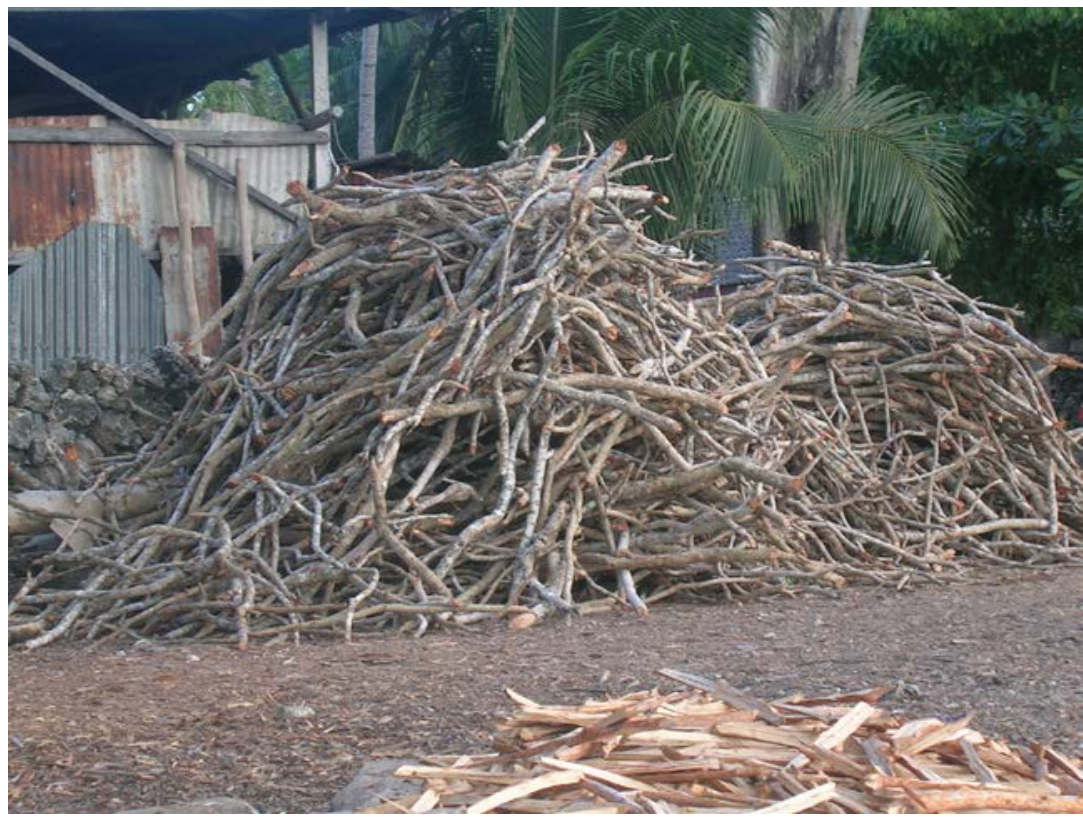

Figure 11.4c Fire wood for food and trepang post harvest cooking

Source: Dedi Supriadi Adhuri

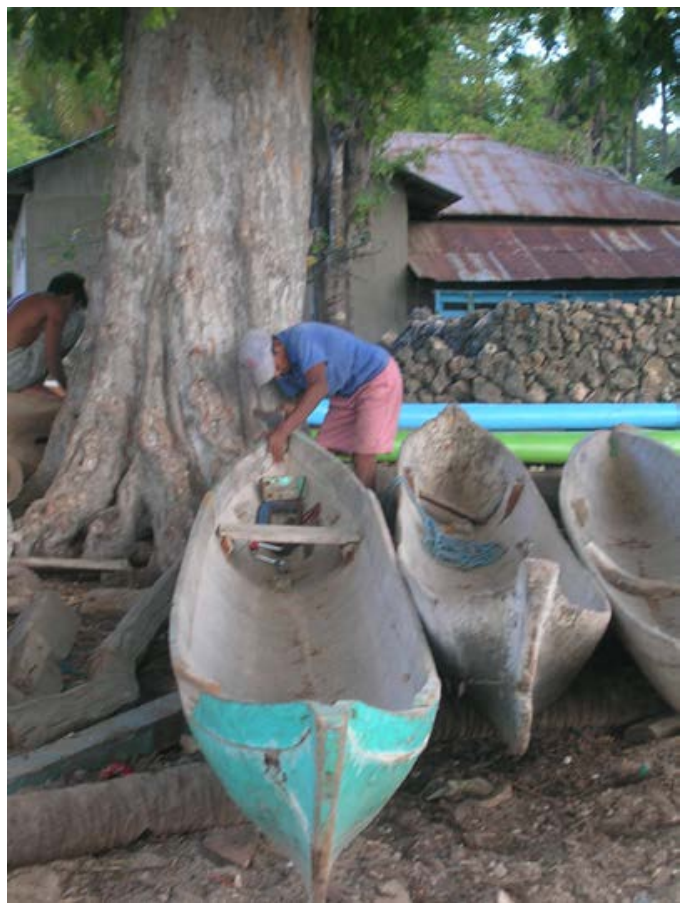

Figure 11.4d Canoes for trepang collecting 
As a result of 'sail power', Oelaba trepang fishing can only be carried out in certain seasons. In the earlier voyages to the MoU Box, fishers arranged mostly two trips in a year, usually between April-May and July-August. Since the closure of Ashmore Reef to fishing in 1988, most of the fishers can only consider one trip per year. Thus, they usually leave Oelaba in July/August, returning home in early October (Carnegie 2008).

In collecting trepang, either by wading or diving, Oelaba fishers do not conduct selective harvesting. They harvest all economically valuable trepang of any size. Carnegie (2008) documents about a dozen different species of trepang gathered by Oelaba fishers. These include koro batu (black teatfish, Holothuria whitmaei), koro susu (white teatfish, Holothuria fuscogilva), tripang nanas (prickly redfish, Thelenota ananas), kasut (surf redfish, Actinopyga mauritiana), japung (greenfish, Stichopus chloronotus), cerak hitam (lollyfish, Holothuria atra), cerak merah (pinkfish, Holothuria edulis), bintik merah (leopardfish, Bohadschia argus), and others. On being asked about the general trends of the harvest, Oelaba fishers commented that trepang stocks have been decreasing significantly over time. This is actually a strong indicator of over-exploitation, which is corroborated by research conducted by the Commonwealth Scientific and Industrial Research Organisation (CSIRO). In 1998, the CSIRO Division of Marine Resources conducted a survey in the MoU Box and found that 'the sedentary marine living resources on the shallow reefs were heavily depleted with the high-value species over-exploited and the lower value species probably either fully or overexploited' (Skewes et al. 1999, p. iv).

Fishers are well aware of this trend, of course, and understand that continuous pressure on the available resources might well lead to the collapse of the trepang fisheries and their marine economy; however, increases in the price of trepang and the lack of other viable livelihood alternatives have led them to consistently consider trepang fishing as a still-viable livelihood. In thinking about possible solutions to this vicious circle, fishers live in the hope that wider fishing grounds will be opened for exploitation. Some consider going back to or intensifying their old activities in trading and sailing (that is, transporting cargo). In any case, for the latter form of employment in particular, they will need a small engine for their lambo, as sail-powered vessels are inappropriate for inter-island cargo transportation. Increased business competition and increasingly frequent extreme weather events, which are overwhelmingly blamed on global climate change, mean there is a need for better-equipped vessels, in terms of both safety and speed. 


\section{Oesapa-based trepang fishery}

Oesapa village is a large kelurahan (village administrative unit) in the city of Kupang. It is located on the western end of Timor Island. In 2005, Oesapa's population numbered 25 813, comprising some 8001 households. The fishing centre is located in one corner of the village, close to the food and trade market. This is also the area where most fishing households are located. The majority of the population living here are migrants or descendants of migrants from South Sulawesi. In terms of ethnicity, they are either Bugis or Makassarese, or a combination of both. The settlement was established by the first generation of these migrants in 1994. Originally fishermen, or wives or dependants of fishermen, they migrated to Oesapa to further their livelihoods. Prior to the migration process, they fished for trepang in the coastal areas of their hometowns in South Sulawesi or in the waters of neighbouring islands. It was the endless search for better trepang resources that ultimately led to the move to Oesapa. The move was inspired by rumours that trepang were in abundance in the waters bordering Indonesia and Australia. When they checked the official map of the area, popularly known as 'Map No. 367', and saw the presence of a large number of reefs, indicating the ideal habitat for trepang, they were convinced that the rumours might be true. Based on their annual trepang catches, this rumour has indeed proven true.

Nonetheless, by definition, Oesapa fishers fall into the category of 'nontraditional' or 'modern' fishers. They use smaller boats compared with the size of the lambo used in Oelaba. Their boats, which are called jolor (Figure 11.5), weigh around $4-5$ gross tonnes. These relatively small boats are equipped with two or three 23-26 hp engines (Figure 11.6). Although Oesapa fishers use a spear gun and fishing line, the main gear used is a set of air compressors (Figure 11.6). ${ }^{4}$ Oesapa fishers also fish for fin-fish using a spear gun and line, but their primary fishing target is trepang. In search of the latter, they will dive as deep as their air hose can accommodate, which is close to $40 \mathrm{~m}$.

4 According to one informant, the Oesapa had adopted the air compressor for fishing/diving in 1970s, in South Sulawesi, well before the move to Kupang. 
11. Traditional and 'modern' trepang fisheries on the border of the Indonesian and Australian fishing zones

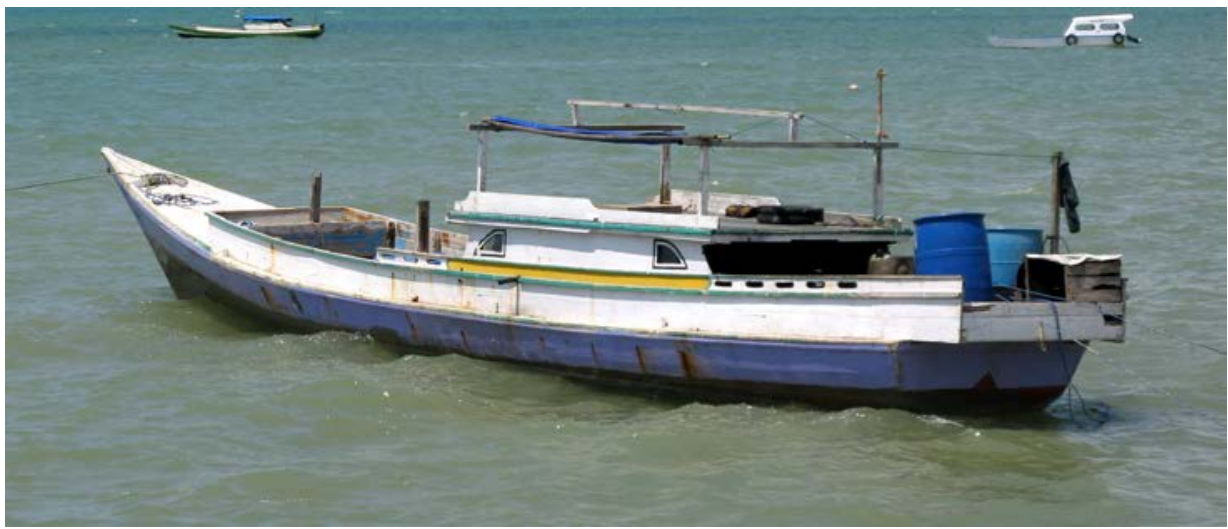

Figure 11.5 'Jolor'

Source: Dedi Supriadi Adhuri

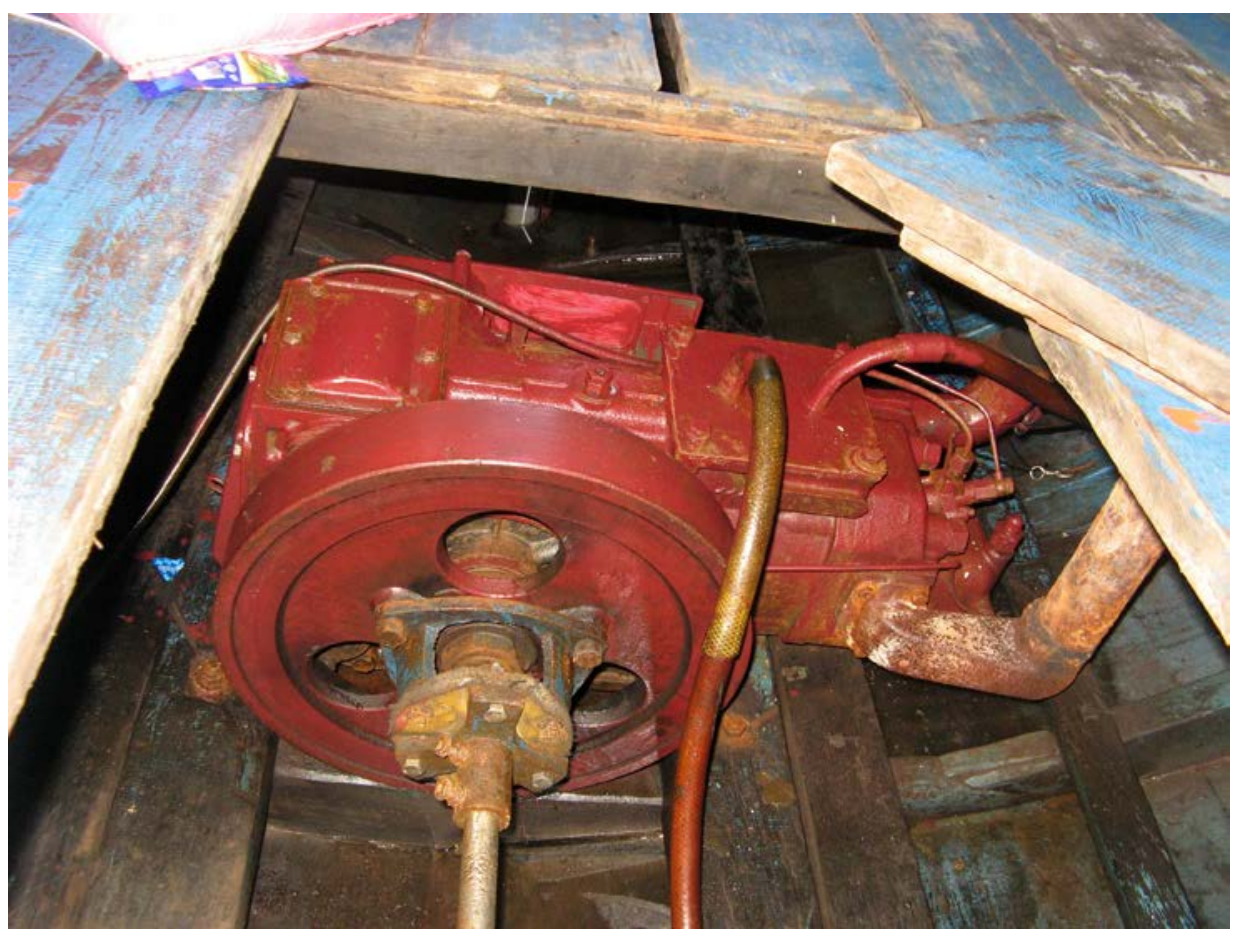

Figure 11.6a The engine

Source: Dedi Supriadi Adhuri 
Macassan History and Heritage

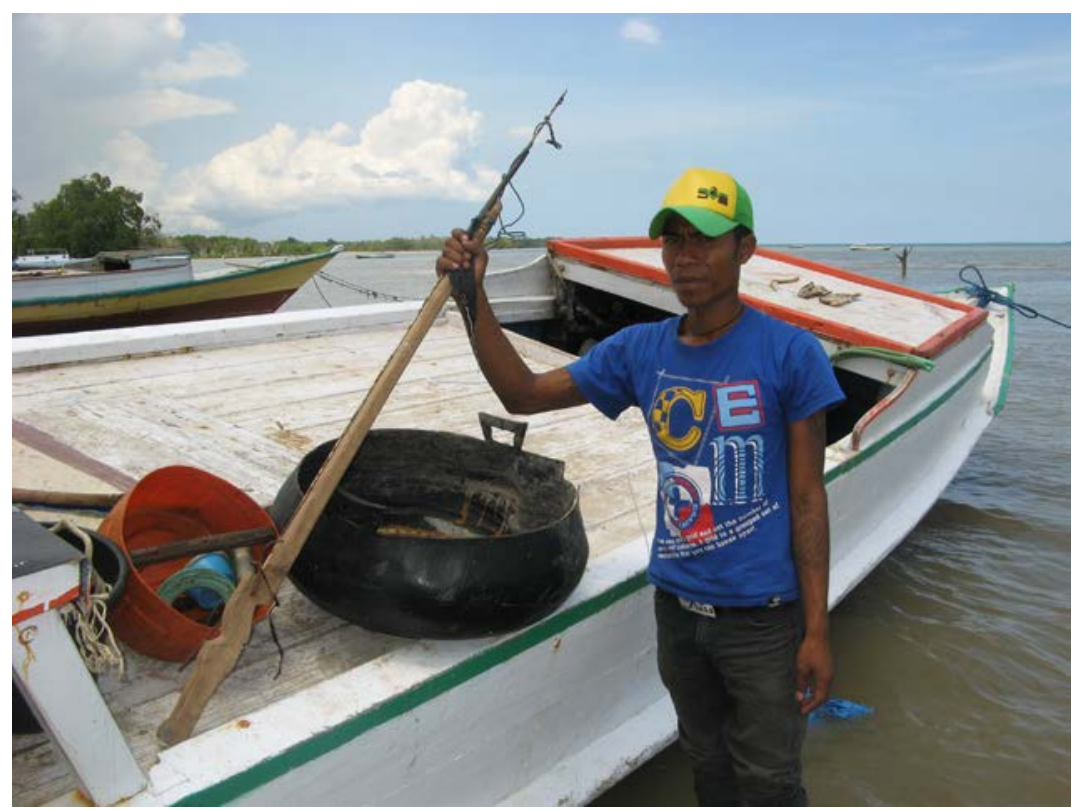

Figure 11.6b A fisher showing a spear and gun

Source: Dedi Supriadi Adhuri

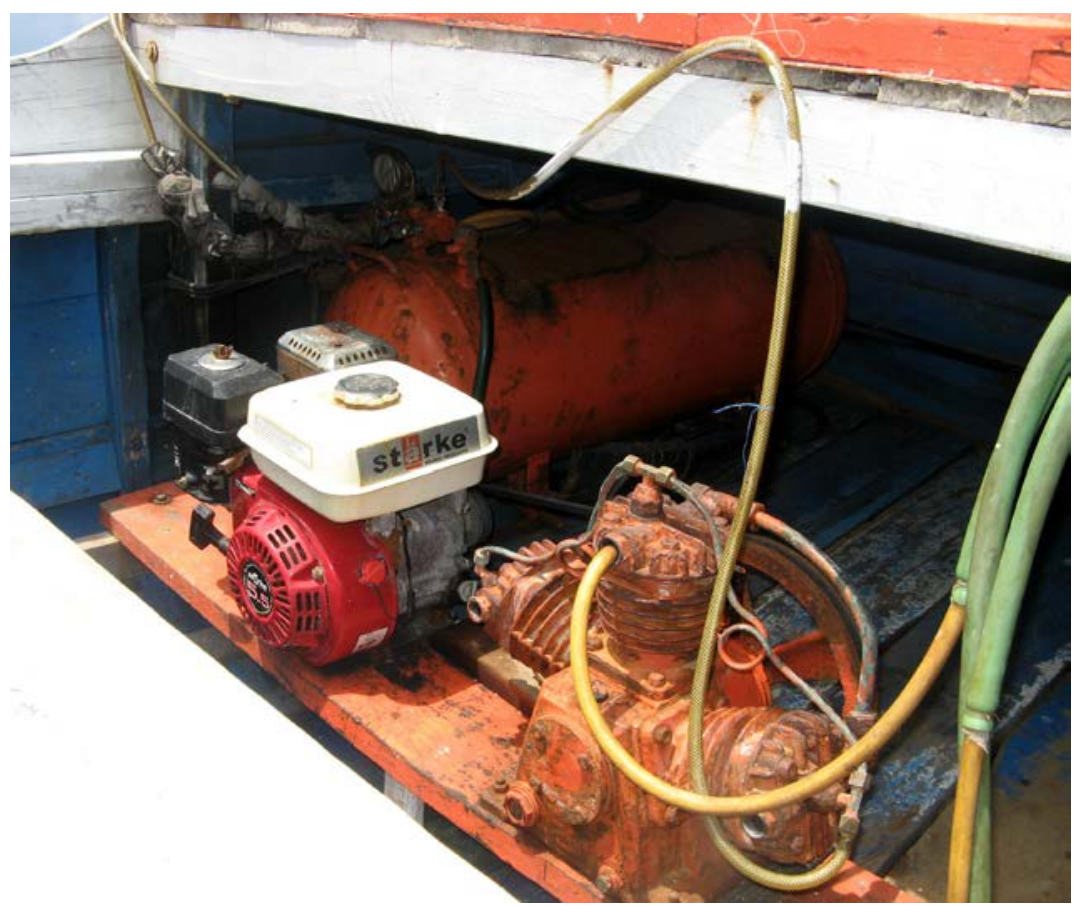

Figure 11.6c A compressor 
11. Traditional and 'modern' trepang fisheries on the border of the Indonesian and Australian fishing zones

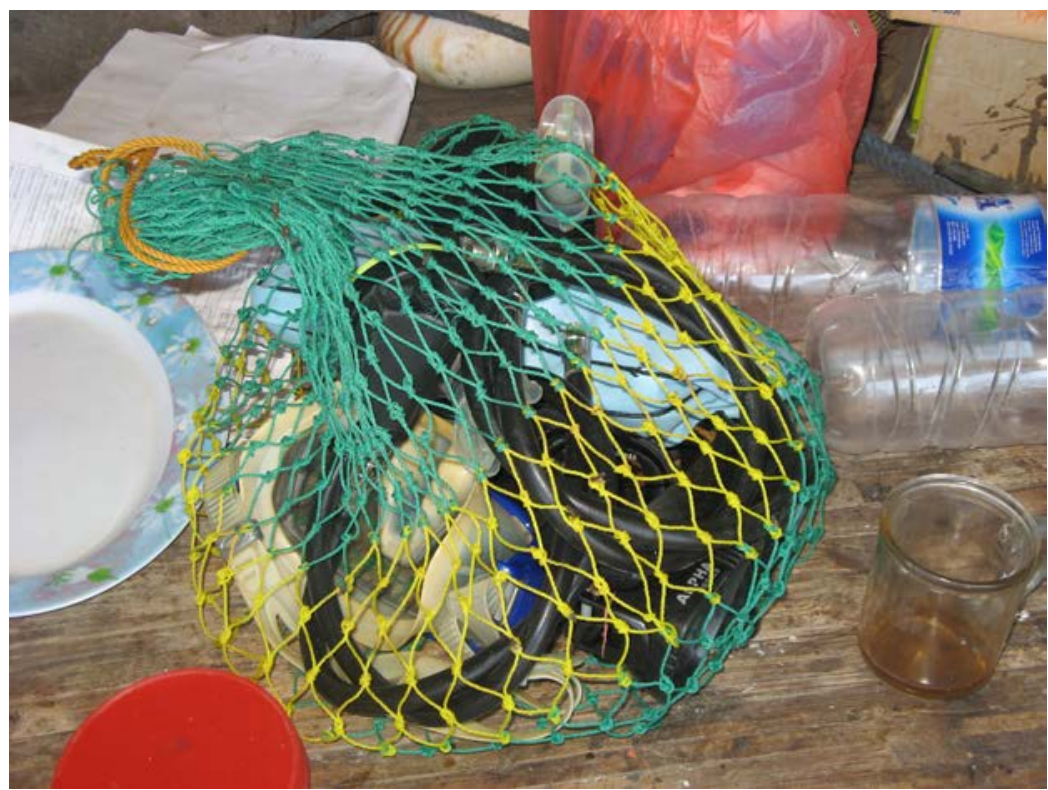

Figure 11.6d Diving equipment

Source: Dedi Supriadi Adhuri

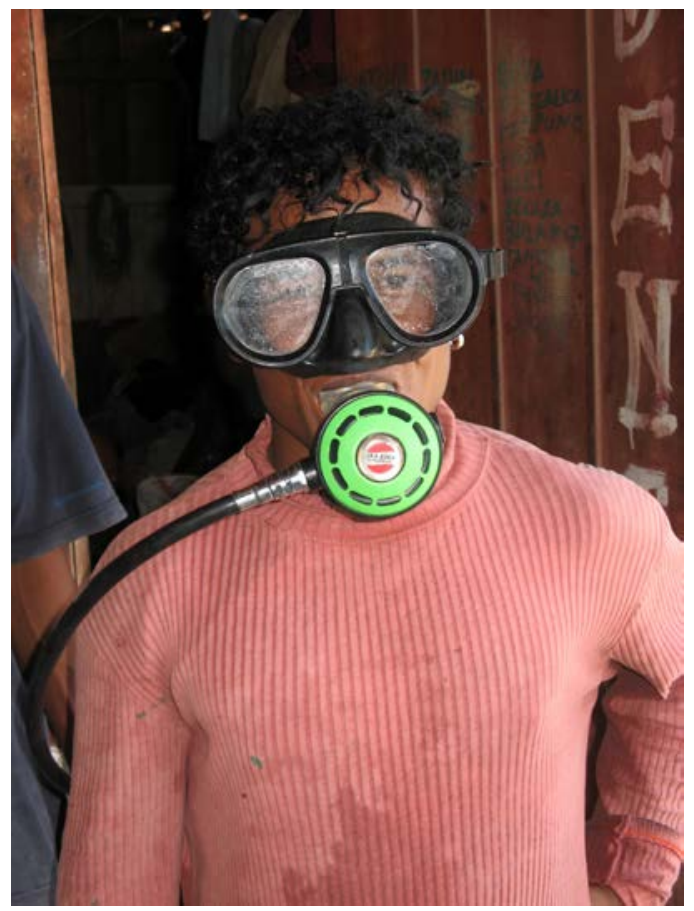

Figure 11.6e A fisher showing how to wear diving mask 
Unlike with the lambo vessels in Oelaba, fishing trips in Oesapa do not depend on wind for power. Engines make it possible for them to go fishing at any time. Because they fish in comparatively small vessels, only very strong wind and waves constrain their fishing activities, as these threaten their safety. In this regard, they are acutely familiar with the 'musim angin' (windy season) that falls between January-February and June-August. During these months, the wind blows strongly, causing strong waves. Thus, the sea is difficult and dangerous to navigate. Other months are known as musim teduh (calm season). This is the season when the Oesapa tend to go fishing because the sea is calm due to the absence or low levels of wind. Since their trips only last between four and seven days, during the calm season they can make as many as four trips a month. Oesapa fishers are lucky if they can make more than two trips a month during the windy season. The extreme weather during the windy season sometimes does not allow for even a single fishing trip.

It is interesting to note that while Oesapa fishers dive at deeper depths with the support of oxygen from the compressor, albeit with a higher risk of suffering decompression illnesses, they are careful to practise selective harvesting. Fishers commented that they only harvest large-sized trepang, and prioritise economically valuable species, such as koro putih (white teatfish, Holothuria fuscogilva) and tripang nanas (prickly redfish, Thelenota ananas). When conducting site visits in September 2011, observation revealed that the average individual size of their catch was $2.3 \mathrm{~kg}$. This is calculated from the average size of the dried trepang, which is $700 \mathrm{~g}$. The dried weight is usually around 30 per cent of the original (wet) weight. Although some trepang species, such as tripang nanas (prickly redfish, Thelenota ananas) grow faster, reaching a comparatively large size in a short time, more than $2 \mathrm{~kg}$ of wet catch is considered a very large individual size for trepang. Most probably it is a well-matured individual. Interviews and field observation found that Oesapa fishers catch several species of trepang. The most targeted species were koro putih (white teatfish, Holothuria fuscogilva), tripang nanas (prickly redfish, Thelenota ananas) and tripang hitam (black teatfish, Holothuria whitmaei). These are the largest and most expensive species. In the absence of these species, however, they also collect low-value species, but still tend to harvest relatively large specimens. Table 11.2 shows these targeted species and their prices in September 2011.

Unlike Oelaba fishers, whose fishing is specifically focused in the MoU Box, Oesapa trepang fishers cover much wider areas. Their fishing grounds include, on the one hand, a variety of reefs stretching from the west to the east of the Indonesia, Australia and Timor-Leste border; and, on the other, coastal areas of Timor, Rote and surrounding islands. The former area is the preferred fishing ground during the calm season. Fishing during the windy season, if the fishers manage to go out, is mostly conducted in the latter area. Fishing in the reefs on 
the border zone between Indonesia and Australia means that sometimes they are in the area of the overlapping claim of the two countries where the water column is under Indonesian authority and the seabed belongs to Australia. This effectively means that they often fish for trepang illegally. As mentioned earlier, the agreement between Indonesia and Australia stipulates that the seabed of this area is under the control of the Australian Government. Indonesian sea bed fishing without Australian permission is therefore considered illegal.

Table 11.2 Main target species and local market price

\begin{tabular}{|l|r|l|r|}
\hline \multicolumn{1}{|c}{ Species } & Price per kg (Rp) & Species & 000 \\
\hline $\begin{array}{l}\text { koro putih (white teatfish, } \\
\text { Holothuria fuscogilva) }\end{array}$ & 550000 & $\begin{array}{l}\text { kuning (elephant trunk fish, } \\
\text { Holothuria fuscopunctata) }\end{array}$ & 200000 \\
\hline koro pake (?) & 400000 & $\begin{array}{l}\text { gamat (curryfish, Stichopus } \\
\text { hermanni) }\end{array}$ & 150000 \\
\hline $\begin{array}{l}\text { tripang nanas (prickly } \\
\text { redfish, Thelenota ananas) }\end{array}$ & 250000 & $\begin{array}{l}\text { bintik (leopard fish, } \\
\text { Baradschia argus) }\end{array}$ & 40000 \\
\hline $\begin{array}{l}\text { tripang hitam (black } \\
\text { teatfish, Holothuria } \\
\text { whitmaei) }\end{array}$ & 45000 & \\
\hline
\end{tabular}

Source: Dedi Supriadi Adhuri

Many fishers in Oesapa have been visited by both Australian and Indonesian fisheries officers whose task it is to educate them on the regulations for fishing in these border areas. Some of them have a map, provided to them by either the Indonesian Marine and Fisheries Department's staff or the Australian officials who visited them for the purposes of 'socialising' the Indonesian and Australian agreement relating to fishing in the border zone. The fishers in possession of this map are then expected to have a good understanding that fishing for trepang in the area of overlapping claims is forbidden; ${ }^{5}$ however, often the fishers concerned are at a loss to understand why in this area fishing for fin-fish is allowed while fishing for sedentary species such as trepang and trochus is forbidden. Under Indonesian fishing regulations, trepang and other sedentary species are considered and categorised as the same thing - that is, as a 'fish resource'. For many fishers, the bilateral agreement concerning the different regime of authorities and management over the water column and the seabed is particularly confusing. In fact, some argue that even if the seabed is under the jurisdiction of the Australian authorities, it is difficult to believe that the sedentary species can live on the seafloor without the water column above. So, as the argument goes, in relation to sedentary species in particular, it does not make sense to apply the two management regimes.

5 In the map distributed to the fishers, this area is shaded with an image of trepang crossed out, indicating that it is not allowed to be gathered in this zone. 


\section{Conclusion}

Trepang fisheries along the border of Indonesia and Australia are certainly a social, economic and heritage 'tradition' worth honouring, appreciating and even conserving. Historical evidence demonstrates that these fisheries have existed for at least four centuries without much disruption. This tradition, by the way, has been handed down from one generation to the next. It entails a deep understanding of sailing and a depth of traditional ecological knowledge of marine species such as trepang and its habitat. In fact, in certain contexts, the traditional knowledge and skills of trepang fishers might exceed those of the scientists working on trepang. An Australian Fisheries Management Authority (AFMA) fisheries official, for example, has informed me that his expert team assessing the status of trepang in the MoU Box did not find many trepang in a certain transect plot; however, when he asked Oelaba fishers to do the same survey, they were able to gather many more trepang than his highly qualified Australian team. As argued throughout this book, the Macassan trepang tradition has also contributed to much cultural exchange between different groups of people, the products of which might not exist without the trepang and the Macassan trepang industry in particular. Economically, present-day trepang fisheries are the source of livelihoods for many people from different places in Indonesia. Of course, this industry has also created competition, conflict and other socio-ecological problems; but the negatives should not overshadow the positives.

Unfortunately, the construction of the modern Australian and Indonesian political states and economic systems has led to most people thinking primarily of the political and economic interests of their own state and their own fellow citizens, even if this is at the cost of their nearest neighbours. Thus, in this context, the word 'tradition' has become an instrument for the 'politics of exclusion' (Campbell and Wilson 1993). The implementation of this conception to the Oelaba people, who are regarded as the embodiment of 'traditional' fishers in comparison with the Oesapa community, who are formally identified as 'nontraditional' or 'modern' fishers, is a case in point. Little can be said or done in regards to this, as it is what state regulations and agreements say it is.

Having examined the trepang fisheries in the two communities, however, the policy and its implementation do not always accord with the reality. As it stands, formal regulations suggest that Oelaba and Oesapa fishers represent two distinct or unrelated fisheries, which implies that they are either traditional or contemporary fishers. Is this the case in reality? We should agree that Oelaba fishers fall into the category of 'traditional' fishers concerning the fishing methods and vessels they use; however, they only became trepang fishers in the 1980s. This means that historically they do not share the heritage of those who for 
decades have used traditional boats and gear to fish in Australian waters. In fact, they were even not fishers when the term of 'traditional fishermen' was formally defined through the signing of the MoU in 1974. Of course, we may argue that by birthright they might be part of a Macassan heritage. Their South Sulawesibased hereditary lineage certainly suggests that they are the descendants of, at least partly, the Bugis, Makassarese and Butonese who initially established the Macassan trepang fishery in Australian waters in centuries past. But, if this argument is valid, it should also be applied to the Oesapa fishers who are almost 100 per cent Bugis and Makassarese and thus by rights can be labelled latterday Macassans. They might well be direct descendants of those involved in the Makassar-Marege' voyages. Or, at least, since they have been fishers for the majority of their professional lives, it could be argued that they are culturally living embodiments of the Macassan tradition.

Finally, it is worth noting that formally one of the reasons for the declaration of the MoU Box and accompanying regulations relating to the border area is the need to establish a better process of transnational fisheries management. In that context, to some extent, we can judge whether 'traditional' trepang fisheries represented by the Oelaba fishery are performing better than those of the contemporary Oesapa. On the one hand, the fact that Oelaba fishers can only exploit the MoU Box seasonally, based on the direction of the wind, is good, at least from a management perspective. It acts as natural closed and opened seasons for the fishery in question. This can reduce pressure on the marine resource as well as the associated ecosystem. On the other hand, nonselective harvesting during the collection time, which usually lasts for months, might produce a countering negative function to the closed-season benefit. This means the absence of pressure during the closed season might be overridden by the exploitative pressure during the harvesting season. Tellingly, the fact that the harvest has decreased significantly over time indicates that the traditional fishing practice is not sustainable.

In contrast with the Oelaba, the selective harvest conducted by Oesapa fishers theoretically might produce a better result for the sustainability of both the marine resources in question and the fishers' fishing economy. In saying this, however, I do not argue that contemporary fishing is necessarily better than traditional methods. The point is that both practices contain positive and negative elements. Thus, the formulation of better management should be based on a strong understanding of both the impact and the historical contours of both practices. Such an understanding would suggest that the exclusion and/or inclusion of either practice - based on the type of fishing vessel or gear usedfrom the MoU and surrounding area might not be the best choice for both the people and the resources concerned. As many key stakeholders would agree, a 
thorough and comprehensive understanding of the entire fishing practice and the closely related socioeconomic context of the people concerned is urgently needed.

\section{References}

Bach, J. P. S. (1955) The Pearling Industry of Australia: An account of its social and economic development, Canberra: Commonwealth of Australia.

Campbell, B. and B. V. E. Wilson (1993) The Politics of Exclusion: Indonesian fishing in the Australian Fishing Zone, Perth: Indian Ocean Centre for Peace Studies \& the Australian Centre for International Agricultural Research.

Carnegie, M. A. (2008) Place-based livelihoods and post-development challenges in eastern Indonesia, Unpublished dissertation, The Australian National University, Canberra.

Commonwealth of Australia (1997) Australia-Indonesia Maritime Delimitation Treaty, Twelfth Report, Canberra: Parliament of the Commonwealth of Australia.

Earl, G. W. (1937) The Eastern Seas: Or voyages and adventures in the Indian archipelago in 1832-33-34, London.

Fox, J. J. (1977) 'Notes on the southern voyages and settlements of the SamaBajau', Bijdragen Tot de Taal-, Land-en Volkenkunde, 133 (4), pp. 459-65.

Fox, J. J. and S. Sen (2002) A study of the socio-economic issues facing traditional Indonesian fishers who access the MOU Box, A report for Environment Australia, Canberra, <http://rspas.anu.edu.au/people/personal/foxxj_rspas/ Fishermen_MOU_BOX.pdf> [accessed 14 January 2012].

Fox, J. J (2009) Legal and Illegal Indonesian Fishing in Australian Waters. In R. Cribb and M. Ford (eds) Indonesia beyond the Water's Edge: Managing an Archipelagic State. Singapore: Institute of Southeast Asian Studies (ISEAS), pp. 195-220.

Johannes, R. E. and M. Riepen (1995) Environmental, economic and social implications of the live reef fish trade in Asia and the western Pacific, Report funded by The Nature Conservancy, the South Pacific Forum Fisheries Agency \& Pew Scholarship in Conservation and the Environment.

Macknight, C. C. (1976) The Voyage to Marege': Macassan trepangers in northern Australia, Carlton, Vic.: Melbourne University Press. 
Sadovy, Y. and M. Liu (2004) Report on current status and exploitation history of reef fish spawning aggregations in eastern Indonesia, Western Pacific Fisher Survey Series Vol. 6, Hong Kong: Society for the Conservation of Reef Fish Aggregations.

Schwerdtner Máñez, K. and S. C. A. Ferse (2010) 'The history of Makassan trepang fishing and trade', PLoS ONE, 5 (6), p. el1346, <doi:10.1371/ journal.pone.0011346>

Skewes, T. D, D. M. Dennis, D. R. Jacobs, S. R. Gordon, T. J. Taranto, M. Haywood, C. R. Pitcher, G. P. Smith, D. Milton and I. R. Poiner (1999) Survey and Stock Size Estimates of the Shallow Reef (0-15 M Deep) and Shoal Area (15-50 M Deep) Marine Resources and Habitat Mapping within the Timor Seas MOU74 Box. Volume 1: Stock estimates and status, Canberra: CSIRO.

Stacey, N. (2001) Crossing borders: implications of the Memorandum of Understanding on Bajo fishing activity in northern Australian waters, Paper presented at Understanding the Cultural and Natural Heritage Values and Management Challenges of the Ashmore Region, 4-6 April, Darwin.

Stacey, N. (2007) Boats to Burn: Bajo fishing activity in the Australian fishing zone, Asia-Pacific Environment Monograph 2, Canberra: ANU E Press.

Sutherland, H. (2000) 'Trepang and wangkang: the China trade of eighteenthcentury Makassar c. 1720s-1840s', Bijdragen tot de Taal-, Land- en Volkenkunde (BKI), 156, pp. 451-72.

Wilson, R. (2009) Reducing illegal fishing in the region-an Australian experience, PowerPoint presentation at Regional Plan of Action meeting, Manado, Indonesia. 